\title{
The Role of Gut Hormones in Obesity
}

\section{Review Article}

Authors: Jessica KW Mok Mon, Janine M Makaronidis $^{1,2,3}$, Rachel L Batterham ${ }^{1,2,3}$

Affiliations

1. Centre for Obesity Research, Rayne Institute, Department of Medicine, University College London, London UK

2. University College London Hospital (UCLH) Bariatric Centre for Weight Management and Metabolic Surgery, University College London Hospital, London, UK and

3. National Institute of Health Research, UCLH Biomedical Research Centre, London, UK

\section{Correspondence to:}

Professor Rachel L Batterham

Centre for Obesity Research

Division of Medicine

Rayne Building

5 University Street

WC1E 6JF

London

Email: r.batterham@ucl.ac.uk

\section{Funding Bodies}

National Institute for Health Research (NIHR), the Rosetrees Trust, the Stoneygate Trust, Robert Luff Trust and Sir Jules Thorn Trust

Declarations of interest: none 


\section{Abstract}

The worldwide obesity epidemic represents a severe threat to global health and is driving the scientific quest for a greater understanding of the mechanisms that regulate bodyweight, in order to develop effective preventative and therapeutic strategies. These research efforts have identified gut hormones as key regulators of energy and glucose homeostasis and have implicated them in the pathogenesis of obesity, the weight recidivism that frequently plagues dietary interventions and the marked changes in eating behaviour, weight reduction and metabolic benefits that accompany bariatric surgery. Consequently, therapeutic strategies aimed at modulating gut hormone levels or targeting their receptors are now being using to treat people with obesity and obesity-associated diseases, such as type 2 diabetes, and represent the most promising therapeutic avenue to combat the obesity epidemic.

\section{Keywords:}

Gut hormones; obesity; obesity treatment; weight loss, PYY, GLP-1 


\section{Introduction}

Obesity, defined by a body mass index (BMI) of $\geq 30 \mathrm{~kg} / \mathrm{m}^{2}$, is a chronic progressive condition that results from excessive adipose tissue accumulation. Obesity-linked diseases, such as type 2 diabetes (T2DM), cardiovascular disease, musculoskeletal disorders, certain cancers and liver disease, impact upon health and reduce life expectancy[1-3]. Conversely, reductions in BMI improve both associated co-morbidity and increase life expectancy. It is estimated that by 2025 , the global obesity prevalence will reach $18 \%$ in men and $21 \%$ in women[2]. Treatments for obesity to date have been limited and unsuccessful in addressing the challenge of the global obesity epidemic.

The key for developing new, effective, treatments for obesity lies in furthering our understanding of the mechanisms regulating bodyweight. The procurement of adequate nutrition is essential for survival and throughout the majority of human evolution food has been scarce, thus it is hardly surprising that multiple systems have evolved to ensure that eating is a priority. Energy homeostasis is controlled by neuronal circuits within the brain, which integrate peripheral signals of energy availability, originating from the gastrointestinal (GI) tract, adipose tissue, muscles, bones, higher cognitive centres and external environmental food cues[4]. Studies employing mouse transgenics, human genetics and human functional brain imaging have provided key insights into the neural pathways underpinning bodyweight regulation. The hypothalamus is recognised as a key region integrating peripheral signals to drive either orexigenic or anorexigenic responses, in a mutually exclusive manner[5]. The melanocortin-4 receptor (MC4R) has been identified as playing a key role in energy homeostasis; see Figure 1 for a more detailed overview[6]. The French philosopher Voltaire stated that "Nothing would be more tiresome than eating and drinking if God had not made them a pleasure as well as a necessity" and it is now clear that in addition to signals of net energy requirements and availability, the drive to eat is also strongly influenced by brain reward systems and these in turn are influenced by signals from the GI tract. Hedonic food cues, which are ever present in our obesogenic environment, drive the desire to eat and even in the absence of an energy requirement, can result in excess energy consumption, weight gain and ultimately obesity[5]. Thus, effective weight management strategies need to target both the homeostatic and hedonic regulation of eating and gut hormones have emerged as prime candidates. Here we review our current understanding of the role of gut hormones in the development and management of obesity. 


\section{The role of gut hormones in energy homeostasis, the pathogenesis and treatment of obesity}

\subsection{Gut hormones: role in energy homeostasis}

The GI tract is the body's first point of contact with ingested nutrients and is metabolically highly active. Enteroendocrine cells (EECs) are distributed across the entire length of the Gl tract. Following a meal, EECs sense nutrients and release a panoply of gut hormones, which act as autocrine, paracrine, and endocrine regulators of energy and glucose homeostasis[7]. For instance, peptide YY 36 (PYY), glucagon-like peptide 1 (GLP-1) and oxyntomodulin (OXM) are released from L-cells; they signal nutrient availability to the brain and have appetite-suppressing effects[7]. GLP-1 also has a profound incretin effect, enhancing glucose-dependent insulin release and inhibiting glucagon secretion[8].

In the absence of nutrient intake, ghrelin, an orexigenic hormone, is secreted by P/D1 cells located primarily in the gastric fundus, leading to increased appetite and energy intake[9]. Circulating ghrelin levels peak prior to nutrient ingestion and decrease rapidly post-meal. Administration of ghrelin to humans promotes a feeling of hunger and stimulates energy intake[10]. The adipokine leptin acts as a signal of long term energy availability and promotes satiety, by modulating orexigenic neurons in the arcuate nucleus of the hypothalamus in an opposing manner to ghrelin[11]. Interestingly, MC4Rs have been localised on P/D1 and L-cells and are thought to regulate ghrelin, GLP-1 and PYY secretion, adding an additional layer of complexity[12]. Table 1 summarises the main known gut hormones, their sites and mechanisms of action.

Importantly, gut hormones act synergistically; GLP-1 and PYY in combination, for instance, have a more potent effect on reducing energy intake, compared to either of the two hormones alone[13, 14]. OXM, GIP and cholecystokinin (CCK) act synergistically with GLP-1 to enhance its effects[14-17]. Furthermore, gut hormones additionally influence energy homeostasis through interactions with the microbiome and bile acids; GLP-1, PYY and leptin act upon vagal signals; and OXM and amylin increase energy expenditure, though the mechanisms underlying these effects remain incompletely understood[18-21].

\subsection{Gut hormones: influence on hedonic pathways}

Hedonic factors are able to generate powerful physiological responses and override homeostatic signals of energy availability, leading to excess energy intake and weight gain. Brain functional imaging studies in humans have shown that gut hormones such as ghrelin, GLP-1 and PYY, modulate neural activity in brain reward regions altering the reward value of food[22-24]. Eating behavior is also strongly influenced by food cues, memory and social factors[5]. Exposure to food-related stimuli can 
stimulate changes in circulating gut hormone levels which in turn act upon brain reward pathways, either increasing in the case of ghrelin, or decreasing in the case of PYY, the reward value of food[25, 26]. Furthermore, the taste and smell of food, which are key contributors toward food choice, are also under the influence of gut hormone action. Gut hormones are present in saliva and their cognate receptors are present on taste buds and the olfactory bulb[27, 28].

\subsection{Gut hormones and the pathogenesis of obesity}

Obesity occurs when energy intake chronically exceeds energy expenditure. By consistently overriding homeostatic signals of energy availability, eating becomes disjointed from energy requirements, and results in dysregulation of the metabolic mechanisms controlling energy homeostasis, including impaired gut hormone secretion[29]. Abnormal gut hormone responses have been demonstrated in adults and children with obesity. Individuals with obesity have blunted ghrelin reductions post-meal, together with reduced circulating baseline and meal-stimulated levels of the anorectic peptides PYY, GLP-1 and neurotensin (NT), compared to individuals with normal weight[29-31].

The directionality of the relationship between weight gain and dysregulated gut hormone responses remains to be fully elucidated. However, a recent study in rats with diet-induced obesity, akin to a western diet, showed reduced circulating PYY and GLP-1 concentrations and a loss of circadian secretion profiles of PYY, GLP-1 and amylin[32]. In addition, sustained exposure to a high-fat diet in mice has been shown to lead to an increase in ghrelin-producing cells[33]. These findings suggest that high energy intake per se may chronically impair gut hormone responsiveness to ingested nutrients. Studies investigating the role of ghrelin in obesity, have shown blunted post-meal ghrelin suppression, loss of pre-meal peaks, along with reduced diurnal variability; these changes are thought to contribute to the lack of a regular meals and the frequent snacking behaviour often observed in individuals with obesity $[9,34]$. In addition, the population and responsivity of intestinal EECs is reduced in people with obesity. A study using biopsied tissue from individuals with obesity also suggests that deregulation of intestinal cell differentiation underlies blunted gut hormone secretion[35].

A recent report of a patient with leptin deficiency, highlights key interactions between gut hormones. Leptin supplementation resulted in significant rises in meal-stimulated insulin and GLP-1, as well as PYY levels[36]. In the same study, ghrelin levels were decreased, highlighting the regulatory effect of leptin on ghrelin secretion and the interplay between leptin, GLP-1 and PYY. Interestingly, while resistance to the effects of insulin and leptin are seen in obesity, sensitivity to the effects of PYY, GLP1 and OXM during exogenous administration is preserved, suggesting these hormones and their receptor systems offer a viable therapeutic target for obesity[17, 30]. 


\subsection{Gut hormone response to an energy deficit diet}

Several lifestyle interventions aimed at engendering weight loss involve restricting energy intake and increasing physical activity to generate a negative energy balance. Although these are successful in the short-term, weight regain is common. Sumithran et al. undertook a study that offered key insights into the biology underlying weight regain. They studied 50 individuals with severe obesity at baseline, after a 10-week very low energy diet (VLED) and 52 weeks after the end of the VLED[37]. Mean weight loss was $13.5 \pm 0.5 \mathrm{~kg}$ and $7.9 \pm 1.1 \mathrm{~kg}$ after 10 and 52 weeks respectively. Participants reported increased hunger and increased desire and urge to eat. After the 10-week VLED a significant reduction in PYY, cholecystokinin (CCK), insulin, leptin and amylin levels were seen, whilst ghrelin, GIP and pancreatic polypeptide (PP) increased. These unfavourable gut hormone changes coupled with increased hunger persisted at 52 weeks[37]. Other authors have reported weight regain, with participants regaining a third or half of the weight loss within 1 year and returning to baseline weight within 3-5 years postintervention[38, 39]. Similar compensatory findings of reduced circulating GLP-1, PYY, CCK, amylin, leptin, increased ghrelin levels and hunger, enhanced food-cue reactivity and increased drive to consume energy-dense food are also reported[40-42]. These compensatory changes may account for the poor long-term efficacy of lifestyle interventions at engendering sustained weight loss. A study comparing a comparable energy deficit induced by either energy restriction or by exercise reported that appetite and acyl-ghrelin levels were increased, whilst PYY was reduced with energy restriction but that exercise led to a reduction in acyl-ghrelin levels and an increase in circulating PYY levels[43]. Other studies also found suppression in appetite and ghrelin following exercise both in low volume sprint interval exercise and endurance exercise[44]. lepsen et al showed a $13 \%$ weight loss induced by 8 weeks of VLED, followed by a 52-week weight-maintenance programme and demonstrated that weight loss maintenance was associated with increased circulating postprandial concentrations of PYY and GLP-1 [45]. It is likely that methodological differences underlie these discrepancies and additional studies are warranted.

\subsection{Gut hormones as mediators of the success of bariatric surgery}

Bariatric surgery is currently the most effective treatment for people with severe obesity leading to marked and sustained weight reduction, improvement or resolution of obesity-associated diseases and increased life expectancy[46]. Importantly, bariatric surgical procedures such as Roux-en-Y gastric bypass (RYGB) and sleeve gastrectomy (SG), lead to weight-independent metabolic benefits[47]. Following bariatric surgery, patients report a marked change in eating behaviour, with reduced appetite, changes in taste and food preference away from energy dense foods [48-50]. Thus, bariatric surgery offers a valuable research platform for furthering our understanding of the role of gut hormones in the regulation of energy and glucose homeostasis. 
It is now established that lifestyle-induced weight loss and bariatric surgery differentially impact upon circulating gut hormone levels. Multiple studies have shown that bariatric surgery engenders elevations in nutrient-stimulated levels of several anorectic hormones including PYY and GLP-1 and a reduction in ghrelin levels is seen post-RYGB, with more marked reductions post-SG[51,52]. These changes are present immediately post-surgery and sustained in the longer term[53,54]. Table 2 summarises gut hormone changes following RYGB and SG and contrasts these with the changes following diet-induced weight loss. Furthermore, cross-sectional studies undertaken in patients with poor versus good weight loss post-surgery revealed that individuals with poor weight loss have increased appetite coupled with lower meal-stimulated GLP-1 and PYY and higher ghrelin levels, compared to those with good weight loss[55]. These studies provide observational evidence for a role of gut hormones in mediating the appetite-reducing effects of bariatric surgery[56]. This hypothesis is further supported by the finding that administration of the somatostatin analogue, octreotide, following bariatric surgery promotes appetite and weight gain[57]. More recently, blockade of GLP-1 and PYY in patients post-RYGB have been shown to lead to a $20 \%$ increase in energy intake, further implicating a key role for GLP-1 and PYY in mediating the appetite reduction observed postsurgery[58].

The mechanisms underlying the post-surgery changes in gut hormones remain incompletely understood, however, increased exposure of EECs to ingested nutrients is thought to play a key role[59]. There is also emerging evidence that following bariatric surgery the number of EEC changes. A recent study reported a reduction in total number of EECs and EECs containing gut hormones in the stomach and duodenum of people with obesity compared to lean individuals[35]. Importantly, 3 months post-SG, there was an increase in EECs normalising numbers to those seen in lean subjects. Furthermore, the expression levels of transcription factors required for differentiation of absorptive and secretory cell lineages were altered, suggesting that the reduction in L-cell gut hormone secretion seen in obesity may be secondary to deregulation in differentiation of intestinal epithelial cell lineages, which is restored post-SG.

\section{Harnessing the gut for the prevention and treatment of obesity and metabolic diseases}

The gut hormone system offers the most tractable therapeutic option for the treatment of obesity and obesity-associated diseases. Intravenous administration of supra-physiological levels of native gut hormones PYY, GLP-1, amylin and OXM leads to reduced appetite and decreased energy intake[18, $26,60,61]$. In the past, a short half-life and pharmacokinetic stability have proven barriers for the 
development of gut hormone-based preparations. However, a multitude of compounds mimicking gut hormone actions are currently under development, heralding a new era of pharmacotherapy for obesity.

Indeed, GLP-1 analogues already have an established role in the management of people with T2DM and people with obesity[62]. The longer acting GLP-1 analogue, semaglutide, has shown promising results in terms of weight loss in early phase studies; a weekly subcutaneous and an oral compound are undergoing phase 3 evaluation[63]. Analogue preparations of GIP and amylin are also being trialled in clinical studies. Strategies aimed at reducing acyl-ghrelin and/or increasing des-acyl-ghrelin are also being developed and show promise. In rodents, inhibition of ghrelin-O-acyltransferase (GOAT), the enzyme required for generating acyl-ghrelin, has been shown to reduce energy intake and bodyweight. Furthermore, administration of des-acylated ghrelin analogue, AZP-531, to people with Prader-Willi syndrome, a genetic syndrome characterised by hyperphagia and increased acylated ghrelin levels, has been reported to decrease hunger, fat mass and weight circumference[64] . Table 3 summarises current pharmacotherapy efforts in different stages of development targeting gut hormones as therapeutic strategies for obesity.

In an attempt to mimic the post-bariatric surgery hormone changes and circumvent compensatory adaptive changes associated with energy restriction, studies combining different gut hormones or targeting multiple systems are in progress. In a study by Tan et al., GLP-1, PYY and OXM were coinfused in participants with obesity, aiming to replicate post-RYGB levels and demonstrated a $32 \%$ reduction in energy intake compare to placebo[65]. Similarly, rodent studies suggest a potential role of CCK as an adjunct to GLP-1 based therapies as well as with amylin and leptin[66]. Other preclinical studies have focused on monomeric GLP-1/GIP/glucagon triagonism with balanced agonism at the GLP-1, GIP, and glucagon receptors which have shown improvement in bodyweight in obese mice[67].

\section{Conclusion}

Obesity and its associated diseases represent a major threat to global health. Research efforts aimed at furthering our understanding of energy homeostasis have identified gut hormones as key regulators of bodyweight acting upon homeostatic and hedonic brain circuits to modify eating behaviour. Changes in circulating gut hormones are implicated in contributing to the development of obesity, the failure of lifestyle intervention and in mediating the profound beneficial effects of bariatric surgery. Consequently, major research efforts are focused on harnessing the body's gut hormone system to treat obesity and obesity-associated diseases. Single agent approaches are already licensed for the 
treatment of people with T2DM or obesity with more efficacious combination approaches in development.

$\underline{\text { Tables }}$

Table 1: The main gut hormones involved in energy homeostasis 


\begin{tabular}{|c|c|c|c|c|}
\hline Gut hormone & Source & Targets & Function & Changes seen in obesity \\
\hline \multicolumn{5}{|l|}{ Anorexigenic } \\
\hline $\begin{array}{l}\text { Glucagon-like- } \\
\text { peptide } 1 \text { (GLP-1) }\end{array}$ & $\begin{array}{l}\text { Enteroendocrine L-cells and } \\
\text { brainstem neurons. } \\
\text { derived GLP-1 is secreted in } \\
\text { response to nutrient sensing } \\
\text { and through EEC stimulation } \\
\text { by bile acids }[8,68]\end{array}$ & $\begin{array}{l}\text { GLP-1 receptors (GLP-1R) are widely } \\
\text { distributed on central and } \\
\text { peripheral organs and tissues, } \\
\text { including the hypothalamus, liver, } \\
\text { skeletal and muscle[30] }\end{array}$ & $\begin{array}{l}\text { Reduces appetite and energy intake, delays } \\
\text { gastric emptying, promotes insulin } \\
\text { secretion, enhance } \beta \text {-cell proliferation, } \\
\text { suppresses glucagon secretion, vagus } \\
\text { stimulation[30] }\end{array}$ & $\begin{array}{l}\text { Individuals with obesity have attenuated } \\
\text { nutrient-stimulated GLP-1 circulating levels } \\
\text { compared to normal weight individuals } \\
\text { [30]. }\end{array}$ \\
\hline $\begin{array}{l}\text { Peptide } \text { YY } \\
\text { (PYY) }\end{array}$ & $\begin{array}{l}\text { Enteroendocrine L-cells, } \\
\text { pancreas and brainstem [68] }\end{array}$ & $\begin{array}{l}\text { PYY exerts its anorectic effect } \\
\text { through Y2R in the hypothalamic } \\
\text { arcuate nucleus [26] }\end{array}$ & $\begin{array}{l}\text { Reduces appetite and energy intake, delays } \\
\text { gastric emptying, promotes insulin } \\
\text { secretion, vagus stimulation }[15,30]\end{array}$ & $\begin{array}{l}\text { Individuals with obesity have attenuated } \\
\text { nutrient-stimulated circulating levels of } \\
\text { PYy compared to normal weight } \\
\text { individuals [30] }\end{array}$ \\
\hline $\begin{array}{l}\text { Oxyntomodulin } \\
\text { (OXM) }\end{array}$ & $\begin{array}{l}\text { Enteroendocrine L-cells co- } \\
\text { secreted with GLP-1[69] }\end{array}$ & 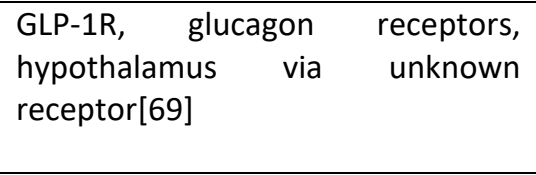 & $\begin{array}{l}\text { Decreases energy intake, delays gastric } \\
\text { emptying, causes glucose-dependent insulin } \\
\text { secretion }\end{array}$ & $\begin{array}{l}\text { Effect of obesity on endogenous OXM is } \\
\text { largely unknown, however exogenous } \\
\text { administration is associated with weight } \\
\text { loss[18] }\end{array}$ \\
\hline $\begin{array}{l}\text { Cholecystokinin } \\
\text { (CCK) }\end{array}$ & $\begin{array}{l}\text { Enteroendocrine } \mathrm{I}-\text { and } \mathrm{L}- \\
\text { cells, pancreas and certain } \\
\text { enteric and central neurons, } \\
\text { in response to nutrient intake } \\
\text { in particular lipids and } \\
\text { protein[68] }\end{array}$ & $\begin{array}{l}\text { CCK-1 receptors in periphery and } \\
\text { CCK-2 receptors in the brain [70] }\end{array}$ & $\begin{array}{l}\text { Inhibit energy intake, via CCK1R on vagal } \\
\text { afferents, inhibit gastric secretion, stimulate } \\
\text { insulin secretion [70] }\end{array}$ & $\begin{array}{l}\text { Satiety effect of CCK attenuated in obesity } \\
\text { and CCK response to oleic acid infusion is } \\
\text { reduced in people with overweight or } \\
\text { obesity compared to normal weight } \\
\text { subjects }[70,71]\end{array}$ \\
\hline $\begin{array}{l}\text { Glucose- } \\
\text { dependent } \\
\text { insulinotropic } \\
\text { polypeptide (GIP) }\end{array}$ & $\begin{array}{l}\text { Enteroendocrine K-cells in } \\
\text { response to dietary lipids[68] }\end{array}$ & $\begin{array}{l}\text { GIP receptor in pancreatic islet cells, } \\
\text { hypothalamus, adipose tissue[72] }\end{array}$ & $\begin{array}{l}\text { Stimulates insulin secretion, anti-apoptotic } \\
\text { function in pancreatic beta cells, reduces } \\
\text { energy } \\
\text { intake[72] }\end{array}$ & $\begin{array}{l}\text { Some studies suggest GIP hypersecretion } \\
\text { in people with obesity[72] }\end{array}$ \\
\hline Neurotensin (NT) & $\begin{array}{l}\text { Enteroendocrine L-cells, CNS, } \\
\text { released in response to } \\
\text { nutrient intake, in particular } \\
\text { fat[73] }\end{array}$ & $\begin{array}{l}\text { NT receptors: NTR1, NTR2, NTR3 } \\
\text { widely distributed in the brain and } \\
\text { periphery[73] }\end{array}$ & $\begin{array}{l}\text { Reduces GI motility and gastric secretion, } \\
\text { stimulates pancreatic and biliary secretion, } \\
\text { facilitates fat translocation, act as an } \\
\text { incretin.[73] }\end{array}$ & $\begin{array}{l}\text { People with severe obesity have lower } \\
\text { circulating NT levels in the fasted state that } \\
\text { normal weight people[31] }\end{array}$ \\
\hline Uroguanylin & $\begin{array}{l}\text { Intestinal epithelial cells, } \\
\text { released in response to } \\
\text { nutrient ingestion. Secreted } \\
\text { as prouroguanylin, enzymatic }\end{array}$ & $\begin{array}{l}\text { Activates guanylyl cyclase } 2 \mathrm{C} \\
\text { (GUCY2C) receptors on intestinal } \\
\text { epithelial cells and the } \\
\text { hypothalamus [74] }\end{array}$ & $\begin{array}{l}\text { Promotes satiety and reduces energy intake. } \\
\text { At intestinal level regulates fluid and } \\
\text { electrolyte balance and cellular } \\
\text { metabolism.[74] }\end{array}$ & $\begin{array}{l}\text { Circulating levels are suppressed in } \\
\text { adolescents with obesity and Intestinal } \\
\text { expression of uroguanylin is diminished in } \\
\text { female paediatric patients with } \\
\text { obesity.[75] }\end{array}$ \\
\hline
\end{tabular}




\begin{tabular}{|c|c|c|c|c|}
\hline & $\begin{array}{ll}\text { conversion } & \text { to } \\
\text { uroguanylin.[74] } & \end{array}$ & & & \\
\hline Gastric leptin & $\begin{array}{l}\text { Gastric chief cells and gastric } \\
\text { endocrine P cells in response } \\
\text { to energy intake and peptide } \\
\text { hormones suck as CCK and } \\
\text { insulin[11] }\end{array}$ & $\begin{array}{l}\text { Leptin receptors located in vagal } \\
\text { afferents[76] }\end{array}$ & $\begin{array}{l}\text { Regulates energy intake; effect is dependent } \\
\text { on nutritional status. In the fasted state, it } \\
\text { inhibits vagal afferents, facilitating increased } \\
\text { energy intake. In the fed state, stimulates } \\
\text { vagal afferents with satiety-inducing } \\
\text { effect.[11] }\end{array}$ & $\begin{array}{l}\text { Suggestion of reduce responses to gastric } \\
\text { distension following energy intake.[76] }\end{array}$ \\
\hline Amylin & $\begin{array}{l}\text { Pancreatic beta cells, co- } \\
\text { secreted with insulin, in } \\
\text { response to nutrient } \\
\text { ingestion and incretin } \\
\text { hormones[61] }\end{array}$ & $\begin{array}{l}\text { Amylin-specific receptors } \\
\text { (composed of the calcitonin } \\
\text { receptor partnered with individual } \\
\text { receptor-modifying proteins) in } \\
\text { nucleus accumbens, the dorsal } \\
\text { raphe, and the hindbrain area } \\
\text { postrema [19] }\end{array}$ & $\begin{array}{l}\text { Supresses postprandial glucagon secretion, } \\
\text { inhibition of energy } \\
\text { intake and slows gastric emptying[61] }\end{array}$ & $\begin{array}{l}\text { Elevated in people with obesity, which may } \\
\text { lead to down-regulation of amylin } \\
\text { receptors and lessen the impact of } \\
\text { postprandial amylin secretion on satiety } \\
\text { and gastric emptying [61] }\end{array}$ \\
\hline FGF19 & $\begin{array}{l}\text { Terminal Ileum following FXR } \\
\text { signalling from activation by } \\
\text { bile acids[77] }\end{array}$ & $\begin{array}{l}\text { FGF receptors } 1,2,3 \text { and } 4 \text {, located } \\
\text { in hepatocytes, cardiac and skeletal } \\
\text { muscle, kidneys, blood vessels and } \\
\text { the CNS [77] }\end{array}$ & $\begin{array}{l}\text { Regulates glucose and lipid metabolism, } \\
\text { stimulates hepatic protein and glycogen } \\
\text { synthesis, increases energy expenditure and } \\
\text { reduces energy intake.[77] }\end{array}$ & $\begin{array}{l}\text { Decreased FGF19 levels reported in people } \\
\text { with obesity and insulin-resistance } \\
\text { compared to normal weight people[77] }\end{array}$ \\
\hline Bile acids & Liver hepatocytes[78] & $\begin{array}{l}\text { Farnesoid X Receptor (FXR) in the } \\
\text { distal ileum and G protein-coupled } \\
\text { TGR5 receptor on surface of L-cells } \\
\text { [78] }\end{array}$ & $\begin{array}{l}\text { Stimulates glycogen synthesis, increases } \\
\text { glycolysis and decreases gluconeogenesis, } \\
\text { increasing insulin sensitive and improve } \\
\text { glucose tolerance[78] }\end{array}$ & $\begin{array}{l}\text { Conflicting results, some studies show that } \\
\text { people with obesity have lower } \\
\text { postprandial BA levels than normal weight } \\
\text { people }\end{array}$ \\
\hline \multicolumn{5}{|l|}{ Orexigenic } \\
\hline Ghrelin & $\begin{array}{l}\text { P/D1-type cells in the gastric } \\
\text { antrum and fundus and } \\
\text { duodenum[30] }\end{array}$ & $\begin{array}{l}\text { Growth hormone secretagogue } \\
\text { receptor type 1a (GHSR1a), after } \\
\text { acylation by ghrelin O-acyl- } \\
\text { transferase (GOAT) into acyl- } \\
\text { ghrelin, hypothalamus, vagus } \\
\text { nerve[9] }\end{array}$ & $\begin{array}{l}\text { Increase appetite, promotes nutrient intake, } \\
\text { increases gastric emptying, gastric acid } \\
\text { production, decreases insulin secretion[9]. }\end{array}$ & $\begin{array}{l}\text { Ghrelin secretion is dysregulated in people } \\
\text { with obesity. Diet induced obesity causes } \\
\text { resistance to the effects of ghrelin in } \\
\text { hypothalamic appetite regulating } \\
\text { neurones. Decrease in ghrelin following } \\
\text { energy ingestion is blunted in individuals } \\
\text { with obesity. However, weight loss is } \\
\text { associated with increases in ghrelin levels. } \\
\text { [30] }\end{array}$ \\
\hline
\end{tabular}


Table 2: Changes in circulating gut hormones following RYGB, SG and diet induced weight loss

\begin{tabular}{|c|c|c|c|}
\hline Gut hormone & Changes in RYGB & Changes in SG & Changes in Dieting \\
\hline \multicolumn{4}{|l|}{ Anorexigenic } \\
\hline GLP-1 & $\begin{array}{l}\text { Fasting levels: } \leftrightarrow \\
\text { Post prandial levels: } \\
\uparrow \uparrow \uparrow \\
{[30,51,52,55]}\end{array}$ & $\begin{array}{l}\text { Fasting levels: } \leftrightarrow \\
\text { Post prandial levels: } \\
\text { 个个 } \\
{[51,52]}\end{array}$ & $\begin{array}{l}\leftrightarrow \text { or } \downarrow \\
{[40]}\end{array}$ \\
\hline PYY & $\begin{array}{l}\text { Fasting levels: } \leftrightarrow \text { or } \uparrow \\
\text { Post prandial levels: } \\
\uparrow \uparrow \uparrow \\
{[30,51,55,79]}\end{array}$ & $\begin{array}{l}\text { Fasting levels: } \leftrightarrow \text { or } \\
\uparrow \\
\text { Post prandial levels: } \\
\uparrow \uparrow \\
{[51,52]}\end{array}$ & $\leftrightarrow$ or $\downarrow[37,40]$ \\
\hline Oxyntomodulin & 个 [69] & & \\
\hline CCK & $\uparrow[30,55]$ & 个个 [52] & $\downarrow[37,40]$ \\
\hline GIP & $\begin{array}{l}\leftrightarrow \text { or } \downarrow \\
{[72]}\end{array}$ & $\begin{array}{l}\leftrightarrow \text { or } \downarrow \\
{[80]}\end{array}$ & $\uparrow[37]$ \\
\hline Neurotensin & 个个[81] & & \\
\hline Gastrin & $\leftrightarrow$ or $\downarrow[82]$ & $\leftrightarrow$ or $\downarrow[82]$ & \\
\hline Amylin & $\downarrow[79]$ & & $\downarrow[40]$ \\
\hline FGF19 & $\uparrow[83,84]$ & 个[83] & $\leftrightarrow[84]$ \\
\hline Bile acids & $\begin{array}{l}\text { Conflicting data: } \\
\leftrightarrow \text { or } \uparrow \uparrow[83,85]\end{array}$ & $\begin{array}{l}\text { Conflicting data: } \\
\leftrightarrow \text { or } \uparrow[83,85]\end{array}$ & $\downarrow[86]$ \\
\hline \multicolumn{4}{|l|}{ Orexigenic } \\
\hline Ghrelin & $\begin{array}{l}\downarrow \text { in the first weeks } \\
\text { longer-term effects are } \\
\text { controversial: } \leftrightarrow, \downarrow \text { or } \\
\uparrow[30]\end{array}$ & $\begin{array}{l}\text { Fasting levels: } \downarrow \\
\text { Postprandial levels: } \\
\downarrow \downarrow[51,80]\end{array}$ & $\begin{array}{l}\leftrightarrow \text { or } \uparrow, \text { VLCD or } \\
\text { ketogenic diet: } \downarrow \\
{[37,41]}\end{array}$ \\
\hline \multicolumn{4}{|c|}{$\uparrow=$ increase intervention } \\
\hline $\begin{array}{l}\downarrow=\text { decrease inte } \\
\leftrightarrow=\text { no significan }\end{array}$ & & & \\
\hline
\end{tabular}


Table 3: Summary of current pharmacotherapy in development targeting gut hormones for obesity

\begin{tabular}{|c|c|c|c|c|}
\hline Target & Compound & Phase of Study & & $\begin{array}{l}\text { Effects from early phase/animal } \\
\text { studies }\end{array}$ \\
\hline \multirow[t]{4}{*}{ GLP-1 } & Semaglutide weekly SC & $\begin{array}{l}\text { Phase } 3 \\
\text { (NCT03548935) }\end{array}$ & Novo Nordisk & $\begin{array}{l}\text { Weight loss } \\
\text { HbA1c reduction }\end{array}$ \\
\hline & $\begin{array}{l}\text { Efpeglenatide } \\
\text { Weekly SC }\end{array}$ & $\begin{array}{l}\text { Phase } 2 \\
\text { (NCT03353350) }\end{array}$ & Sanofi & $\begin{array}{l}\text { Weight loss } \\
\text { HbA1c reduction }\end{array}$ \\
\hline & $\begin{array}{l}\text { Dulaglutide } \\
\text { Weekly SC }\end{array}$ & $\begin{array}{l}\text { Phase } 3 \\
\text { (NCT01558271) }\end{array}$ & Lilly & $\begin{array}{l}\text { Weight loss } \\
\text { HbA1c reduction }\end{array}$ \\
\hline & Oral Semaglutide[87] & Phase 3 & Novo Nordisk & $\begin{array}{l}\text { Weight reduction } \\
\text { Glucose lowering }\end{array}$ \\
\hline PYY & PYY 3-36 [87] & Phase 1 & Novo Nordisk & $\begin{array}{l}\text { Reduced appetite } \\
\text { Reduced energy intake }\end{array}$ \\
\hline \multirow[t]{3}{*}{ Ghrelin } & $\begin{array}{l}\text { ghrelin-O- } \\
\text { acyltransferase (GOAT) } \\
\text { inhibitor [88] }\end{array}$ & Phase 1 & Takeda & $\begin{array}{l}\text { Reduced energy intake and } \\
\text { reduced meal frequency in mice }\end{array}$ \\
\hline & $\begin{array}{l}\text { Unacylated ghrelin } \\
\text { analogue (AZP-531) }\end{array}$ & $\begin{array}{l}\text { Phase } 2 \\
\text { (NCT02040012) }\end{array}$ & Alize Pharma & $\begin{array}{l}\text { Appetite reduction and weight } \\
\text { loss in mice } \\
\text { Reduced appetite scores, } \\
\text { reduced waist circumference } \\
\text { and fat mass but weight neutral } \\
\text { in Prader-Willi patients }\end{array}$ \\
\hline & GLWL-01 & $\begin{array}{l}\text { Phase } 2 \\
\text { (NCT03274856) }\end{array}$ & $\begin{array}{l}\text { GLWL/ } \\
\text { Eli Lilly }\end{array}$ & $\begin{array}{l}\text { Under evaluation in Prader-Willi } \\
\text { patients and participants with } \\
\text { obesity }\end{array}$ \\
\hline CCK & CCK-1 receptor agonist & $\begin{array}{l}\text { Phase } 1 \\
\text { (NCT00600743) }\end{array}$ & GSK & $\begin{array}{l}\text { Appetite and bodyweight } \\
\text { reduction in mice } \\
\text { Conflicting reports of efficacy in } \\
\text { early human studies }\end{array}$ \\
\hline Amylin & $\begin{array}{l}\text { Long-acting amylin } \\
\text { analogue[87] }\end{array}$ & $\begin{array}{l}\text { Phase } 1 \\
\text { (NCT02958085) }\end{array}$ & $\begin{array}{l}\text { Novo } \\
\text { Nordisk }\end{array}$ & $\begin{array}{l}\text { Weight loss } \\
\text { Reduction in energy intake } \\
\text { Improved glucose tolerance }\end{array}$ \\
\hline
\end{tabular}




\begin{tabular}{|c|c|c|c|c|}
\hline & & & $\begin{array}{l}\text { Boehringer- } \\
\text { Ingelheim }\end{array}$ & \\
\hline GIP & GIP analogue [89] & Phase 1 & $\begin{array}{l}\text { Zealand } \\
\text { Pharma }\end{array}$ & $\begin{array}{l}\text { Insulinotropic effects } \\
\text { Weight neutral in mice }\end{array}$ \\
\hline Glucagon & Glucagon analogue [87] & Phase 1 & $\begin{array}{l}\text { Novo } \\
\text { Nordisk }\end{array}$ & \\
\hline FGF 21 & $\begin{array}{l}\text { Long-acting FGF } 21 \\
\text { analogue }\end{array}$ & $\begin{array}{l}\text { Phase } 1 \\
\text { (NCT01923389) }\end{array}$ & & $\begin{array}{l}\text { Reduced triglycerides, weight } \\
\text { neutral in early human study }\end{array}$ \\
\hline \multicolumn{5}{|c|}{ Combination therapies } \\
\hline GLP-1/PYY & Oral PYY and oral GLP-1 & $\begin{array}{l}\text { Phase } 1 \\
\text { (NCT00822705) }\end{array}$ & & $\begin{array}{l}\text { Appetite suppression } \\
\text { Reduced energy intake }\end{array}$ \\
\hline $\begin{array}{l}\text { PYY/ } \\
\text { Semaglutide }\end{array}$ & $\begin{array}{l}\text { PYY/Semaglutide } \\
\text { combination [87] }\end{array}$ & Phase 1 & $\begin{array}{l}\text { Novo } \\
\text { Nordisk }\end{array}$ & $\begin{array}{l}\text { Appetite suppression } \\
\text { Reduced energy intake }\end{array}$ \\
\hline \multirow[t]{2}{*}{$\begin{array}{l}\text { Glucagon/ } \\
\text { GLP-1 }\end{array}$} & $\begin{array}{l}\text { Glucagon-GLP-1 co- } \\
\text { agonist }\end{array}$ & Phase 1 & $\begin{array}{l}\text { Zealand } \\
\text { Pharma/ } \\
\text { Boehringer } \\
\text { Ingelheim }\end{array}$ & \multirow[t]{2}{*}{$\begin{array}{l}\text { Energy intake reduction } \\
\text { Appetite suppression } \\
\text { Increased energy expenditure }\end{array}$} \\
\hline & $\begin{array}{l}\text { Dual glucagon/GLP-1 } \\
\text { agonist }\end{array}$ & $\begin{array}{l}\text { Phase } 1 \\
\text { (NCT03376802) }\end{array}$ & $\begin{array}{l}\text { Sanofi } \\
\text { AstraZeneca }\end{array}$ & \\
\hline \multirow[t]{2}{*}{ GLP-1/GIP } & $\begin{array}{l}\text { Dual GLP-1/GIP agonist } \\
\text { [90] }\end{array}$ & Phase 1 & Sanofi & Appetite suppression \\
\hline & $\begin{array}{l}\text { Dual GIP/GLP-1 } \\
\text { Receptor Agonist [87] }\end{array}$ & Phase 2 & $\begin{array}{l}\text { Novo } \\
\text { Nordisk }\end{array}$ & $\begin{array}{l}\text { Decreased bodyweight and total } \\
\text { cholesterol, improved glycemic } \\
\text { control in T2DM patients }\end{array}$ \\
\hline $\begin{array}{l}\text { Amylin/ } \\
\text { Calcitonin }\end{array}$ & Dual agonist [91] & Phase 1 & Lilly/Nordic & $\begin{array}{l}\text { Sustained weight loss, improved } \\
\text { glucose homeostasis in rodents }\end{array}$ \\
\hline $\begin{array}{l}\text { GLP-1/ } \\
\text { GIP/glucagon }\end{array}$ & Tri-agonist [87] & Phase 1 & $\begin{array}{l}\text { Novo } \\
\text { Nordisk }\end{array}$ & $\begin{array}{l}\text { Inhibits energy intake and } \\
\text { decreases bodyweight in mice }\end{array}$ \\
\hline GLP-1/CCK & $\begin{array}{l}\text { GLP-1:CCK fusion } \\
\text { peptide [92] }\end{array}$ & Phase 1 & & $\begin{array}{l}\text { Reduced energy intake and } \\
\text { weight reduction in obese mice }\end{array}$ \\
\hline
\end{tabular}




\section{Figure Legends}

\section{Figure 1: Hormones that control eating}

Leptin and insulin circulate in concentrations proportionate to body fat mass and decrease appetite by inhibiting neurons that produce the neuropeptides NPY and AgRP, while stimulating melanocortinproducing neurons in the arcuate-nucleus region of the hypothalamus, near the third ventricle of the brain. NPY and AgRP stimulate eating, and melanocortins inhibit eating, via other neurons. Activation of NPY/AgRP-expressing neurons inhibits melanocortin-producing neurons. The gastric hormone ghrelin stimulates appetite by activating the NPY/AgRP-expressing neurons. Gut hormones released from the GI tract in response to eating, including PYY, inhibit these neurons and thereby suppress appetite and decrease energy intake. Reprinted with permission from Nature Publishing Group, Schwartz, M.W. and G.J. Morton, Obesity: keeping hunger at bay. Nature, 2002. 418(6898): p. 595. 
1. Lauby-Secretan, B., et al., Body fatness and cancer-viewpoint of the IARC Working Group. New England Journal of Medicine, 2016. 375(8): p. 794-798.

2. Trends in adult body-mass index in 200 countries from 1975 to 2014: a pooled analysis of 1698 population-based measurement studies with 19.2 million participants. Lancet, 2016. 387(10026): p. 1377-1396.

3. Afshin, A., et al., Health effects of overweight and obesity in 195 countries over 25 years. The New England journal of medicine, 2017. 377(1): p. 13-27.

4. Dokken, B.B. and T.-S. Tsao, The Physiology of Body Weight Regulation: Are We Too Efficient for Our Own Good? Diabetes Spectrum, 2007. 20(3): p. 166-170.

5. Berthoud, H.R., Metabolic and hedonic drives in the neural control of appetite: who is the boss? Curr Opin Neurobiol, 2011. 21(6): p. 888-96.

6. Schwartz, M.W. and G.J. Morton, Obesity: keeping hunger at bay. Nature, 2002. 418(6898): p. 595.

7. Latorre, R., et al., Enteroendocrine cells: a review of their role in brain-gut communication. Neurogastroenterology \& Motility, 2016. 28(5): p. 620-630.

8. Manning, S., A. Pucci, and R.L. Batterham, GLP-1: a mediator of the beneficial metabolic effects of bariatric surgery? Physiology (Bethesda), 2015. 30(1): p. 50-62.

9. Muller, T.D., et al., Ghrelin. Mol Metab, 2015. 4(6): p. 437-60.

10. Druce, M., et al., Ghrelin increases food intake in obese as well as lean subjects. International journal of obesity, 2005. 29(9): p. 1130.

11. Rosenbaum, M. and R.L. Leibel, 20 years of leptin: role of leptin in energy homeostasis in humans. J Endocrinol, 2014. 223(1): p. T83-96.

12. Panaro, B.L., et al., The melanocortin-4 receptor is expressed in enteroendocrine $L$ cells and regulates the release of peptide YY and glucagon-like peptide 1 in vivo. Cell metabolism, 2014. 20(6): p. 1018-1029.

13. De Silva, A., et al., The gut hormones PYY3-36 and GLP-17-36 amide reduce food intake and modulate brain activity in appetite centers in humans. Cell metabolism, 2011. 14(5): p. 700706.

14. Schmidt, J.B., et al., Effects of PYY3-36 and GLP-1 on energy intake, energy expenditure, and appetite in overweight men. American Journal of Physiology-Endocrinology and Metabolism, 2014. 306(11): p. E1248-E1256.

15. De Silva, A., et al., The gut hormones PYY 3-36 and GLP-1 7-36 amide reduce food intake and modulate brain activity in appetite centers in humans. Cell Metab, 2011. 14(5): p. 700-6.

16. Neary, N.M., et al., Peptide YY3-36 and glucagon-like peptide-17-36 inhibit food intake additively. Endocrinology, 2005. 146(12): p. 5120-7.

17. Field, B.C., et al., PYY3-36 and oxyntomodulin can be additive in their effect on food intake in overweight and obese humans. Diabetes, 2010. 59(7): p. 1635-9.

18. Wynne, K., et al., Oxyntomodulin increases energy expenditure in addition to decreasing energy intake in overweight and obese humans: a randomised controlled trial. International journal of obesity, 2006. 30(12): p. 1729.

19. Wielinga, P.Y., et al., Central amylin acts as an adiposity signal to control body weight and energy expenditure. Physiology \& behavior, 2010. 101(1): p. 45-52.

20. Rosenbaum, M., R. Knight, and R.L. Leibel, The gut microbiota in human energy homeostasis and obesity. Trends Endocrinol Metab, 2015. 26(9): p. 493-501.

21. Manning, S. and R.L. Batterham, The role of gut hormone peptide YY in energy and glucose homeostasis: twelve years on. Annu Rev Physiol, 2014. 76: p. 585-608.

22. Makaronidis, J.M. and R.L. Batterham, Obesity, body weight regulation and the brain: insights from fMRI. Br J Radiol, 2018: p. 20170910. 
23. Batterham, R.L., et al., PYY modulation of cortical and hypothalamic brain areas predicts feeding behaviour in humans. Nature, 2007. 450(7166): p. 106-9.

24. Hayes, M.R. and H.D. Schmidt, GLP-1 influences food and drug reward. Current Opinion in Behavioral Sciences, 2016. 9: p. 66-70.

25. Kroemer, N.B., et al., Fasting levels of ghrelin covary with the brain response to food pictures. Addict Biol, 2013. 18(5): p. 855-62.

26. Batterham, R.L., et al., Gut hormone PYY 3-36 physiologically inhibits food intake. Nature, 2002. 418(6898): p. 650.

27. Cummings, D.E., Taste and the regulation of food intake: it's not just about flavor. Am J Clin Nutr, 2015. 102(4): p. 717-8.

28. Zolotukhin, S., Metabolic hormones in saliva: origins and functions. Oral diseases, 2013. 19(3): p. 219-229.

29. Lean, M.E. and D. Malkova, Altered gut and adipose tissue hormones in overweight and obese individuals: cause or consequence? Int J Obes (Lond), 2016. 40(4): p. 622-32.

30. Steinert, R.E., et al., Ghrelin, CCK, GLP-1, and PYY (3-36): Secretory controls and physiological roles in eating and glycemia in health, obesity, and after RYGB. Physiological reviews, 2016. 97(1): p. 411-463.

31. Auguet, T., et al., Low Circulating Levels of Neurotensin in Women with Nonalcoholic Fatty Liver Disease Associated with Severe Obesity. Obesity (Silver Spring), 2018. 26(2): p. 274-278.

*32. Moghadam, A.A., T.H. Moran, and M.J. Dailey, Alterations in circadian and meal-induced gut peptide levels in lean and obese rats. Exp Biol Med (Maywood), 2017. 242(18): p. 1786-1794.

This study investigating the effect of high-fat diet-induced obesity on the daily rhythm and meal-stimuated secretion of gut peptide plasma levels in rats, demonstrated that animals with obesity had altered daily rhythms and meal-induced gut peptide levels even when consuming the same amount of calories than lean rats.

**33. Francois, M., et al., High-fat diet increases ghrelin-expressing cells in stomach, contributing to obesity. Nutrition, 2016. 32(6): p. 709-15.

A study in mice investigating the effect of a high fat diet on ghrelin-expressing cells in the stomach, demonstrating increased numbers of ghrelin precursor-expressing cells and increased affinity of ghrelin-reactive IgG. These findings suggest that chronic exposure to a high fat diet may contribute to the dysregulated ghrelin secretion seen in obesity

34. Briggs, D.I., et al., Diet-Induced Obesity Causes Ghrelin Resistance in Arcuate NPY/AgRP Neurons. Endocrinology, 2010. 151(10): p. 4745-4755.

**35. Wölnerhanssen, B.K., et al., Deregulation of transcription factors controlling intestinal epithelial cell differentiation; a predisposing factor for reduced enteroendocrine cell number in morbidly obese individuals. Scientific reports, 2017. 7(1): p. 8174.

A study using gastric and duodenal tissue biopsies from lean and morbidly obese participants, before and after SG, demonstrating a reduced EEC number and EECs containing gut hormones, compared to lean individauls, which increased to numbers seen in lean participants 3 months post-SG. The authors propose deregulation in differentiation of intestinal epithelial cell lineages in obesity as the underlying mechanism.

**36. Roth, C.L., et al., Changes in Satiety Hormones in Response to Leptin Treatment in a Patient with Leptin Deficiency. Horm Res Paediatr, 2018: p. 1-7. 
A case report of a patient with leptin deficiency, highlighting key interactions between gut hormones. Leptin supplementation resulted in significant rises in meal-stimulated insulin and GLP-1, as well as PYY levels and reduced ghrelin levels were decreased, highlighting the regulatory effect of leptin on ghrelin secretion and the interplay between leptin and GLP$1 /$ PYY.

37. Sumithran, P., et al., Long-term persistence of hormonal adaptations to weight loss. N Engl J Med, 2011. 365(17): p. 1597-604.

38. Dombrowski, S.U., et al., Long term maintenance of weight loss with non-surgical interventions in obese adults: systematic review and meta-analyses of randomised controlled trials. Bmj, 2014. 348: p. g2646.

39. Ross Middleton, K., S. Patidar, and M. Perri, The impact of extended care on the long-term maintenance of weight loss: a systematic review and meta-analysis. Obesity Reviews, 2012. 13(6): p. 509-517.

40. Zhao, X., et al., The Role of Gut Hormones in Diet-Induced Weight Change: A Systematic Review. Horm Metab Res, 2017. 49(11): p. 816-825.

41. Cummings, D.E., et al., Plasma ghrelin levels after diet-induced weight loss or gastric bypass surgery. N Engl J Med, 2002. 346(21): p. 1623-30.

42. Crujeiras, A.B., et al., Weight regain after a diet-induced loss is predicted by higher baseline leptin and lower ghrelin plasma levels. The Journal of Clinical Endocrinology \& Metabolism, 2010. 95(11): p. 5037-5044.

43. King, J.A., et al., Differential acylated ghrelin, peptide YY3-36, appetite, and food intake responses to equivalent energy deficits created by exercise and food restriction. The Journal of Clinical Endocrinology \& Metabolism, 2011. 96(4): p. 1114-1121.

44. Deighton, K., et al., Appetite, gut hormone and energy intake responses to low volume sprint interval and traditional endurance exercise. European journal of applied physiology, 2013. 113(5): p. 1147-1156.

*45. lepsen, E.W., et al., Successful weight loss maintenance includes long-term increased meal responses of GLP-1 and PYY3-36. European journal of endocrinology, 2016. 174(6): p. 775784.

This study used a VLED followed by a 52-week weight-maintenance programme to engender and maintain weight loss and demonstrated that weight loss maintenance was associated with increased circulating postprandial concentrations of PYY and GLP-1.

46. Sjöström, L., Review of the key results from the Swedish Obese Subjects (SOS) trial-a prospective controlled intervention study of bariatric surgery. Journal of internal medicine, 2013. 273(3): p. 219-234.

47. Adams, T.D., et al., Weight and metabolic outcomes 12 years after gastric bypass. New England Journal of Medicine, 2017. 377(12): p. 1143-1155.

48. Behary, P. and A.D. Miras, Food preferences and underlying mechanisms after bariatric surgery. Proceedings of the Nutrition Society, 2015. 74(4): p. 419-425.

*49. Goldstone, A.P., et al., Link Between Increased Satiety Gut Hormones and Reduced Food Reward After Gastric Bypass Surgery for Obesity. J Clin Endocrinol Metab, 2016. 101(2): p. 599609.

A functional brain imaging study administering the somatostatin analogue octreotide to patients post-RYGB demonstrated that suppression of GLP-1, PYY and FGF19 associated with an increased reward response to food images, which also correlated with PYY level reduction. This finding suggests that the altered gut hormone secretion profiles post-RYGB are likely mediating the reduction in food-related reward seen post-RYGB. 
50. Makaronidis, J.M., et al., Reported appetite, taste and smell changes following Roux-en-Y gastric bypass and sleeve gastrectomy: Effect of gender, type 2 diabetes and relationship to post-operative weight loss. Appetite, 2016. 107: p. 93-105.

51. Yousseif, A., et al., Differential effects of laparoscopic sleeve gastrectomy and laparoscopic gastric bypass on appetite, circulating acyl-ghrelin, peptide YY3-36 and active GLP-1 levels in non-diabetic humans. Obesity surgery, 2014. 24(2): p. 241-252.

52. Peterli, R., et al., Metabolic and hormonal changes after laparoscopic Roux-en-Y gastric bypass and sleeve gastrectomy: a randomized, prospective trial. Obes Surg, 2012. 22(5): p. 740-8.

53. le Roux, C.W., et al., Gut hormones as mediators of appetite and weight loss after Roux-en-Y gastric bypass. Annals of surgery, 2007. 246(5): p. 780-785.

54. Jirapinyo, P., et al., A Meta-Analysis of GLP-1 After Roux-En-Y Gastric Bypass: Impact of Surgical Technique and Measurement Strategy. Obes Surg, 2017.

55. Dirksen, C., et al., Gut hormones, early dumping and resting energy expenditure in patients with good and poor weight loss response after Roux-en-Y gastric bypass. International journal of obesity, 2013. 37(11): p. 1452-1460.

56. Santo, M.A., et al., Weight Regain After Gastric Bypass: Influence of Gut Hormones. Obes Surg, 2016. 26(5): p. 919-25.

57. Pucci, A., et al., A case of severe anorexia, excessive weight loss and high peptide YY levels after sleeve gastrectomy. Endocrinology, diabetes \& metabolism case reports, 2015. 2015.

58. Svane, M.S., et al., Peptide YY and glucagon-like peptide-1 contribute to decreased food intake after Roux-en-Y gastric bypass surgery. Int J Obes (Lond), 2016. 40(11): p. 1699-1706.

59. Makaronidis, J.M. and R.L. Batterham, Potential Mechanisms Mediating Sustained Weight Loss Following Roux-en-Y Gastric Bypass and Sleeve Gastrectomy. Endocrinol Metab Clin North Am, 2016. 45(3): p. 539-52.

60. Bagger, J.I., et al., Effect of oxyntomodulin, glucagon, GLP-1, and combined glucagon+ GLP-1 infusion on food intake, appetite, and resting energy expenditure. The Journal of Clinical Endocrinology \& Metabolism, 2015. 100(12): p. 4541-4552.

61. Reda, T.K., A. Geliebter, and F.X. Pi-Sunyer, Amylin, food intake, and obesity. Obesity research, 2002. 10(10): p. 1087-1091.

62. Pi-Sunyer, X., et al., A Randomized, Controlled Trial of $3.0 \mathrm{mg}$ of Liraglutide in Weight Management. New England Journal of Medicine, 2015. 373(1): p. 11-22.

63. O'Neil, P.M., et al., Efficacy and safety of semaglutide compared with liraglutide and placebo for weight loss in patients with obesity: a randomised, double-blind, placebo and active controlled, dose-ranging, phase 2 trial. Lancet, 2018.

*64. Allas, S., et al., AZP-531, an unacylated ghrelin analog, improves food-related behavior in patients with Prader-Willi syndrome: A randomized placebo-controlled trial. PloS one, 2018. 13(1): p. e0190849.

A randomized placebo-controlled trial using AZP-531 in Prader-Willi syndrome, showing decreased hunger, fat mass and weight circumference but no net effect on body weight. Targeting ghreling, may be a successful therapeutic strategy to reduce appetite and engender weight loss in people with obesity.

*65. Tan, T., et al., The effect of a subcutaneous infusion of GLP-1, OXM, and PYY on energy intake and expenditure in obese volunteers. The Journal of Clinical Endocrinology \& Metabolism, 2017. 102(7): p. 2364-2372.

Obese volunteers received co-infusions of GLP-1, OXM and PYY at levels aimed to match those seen post-RYGB. A $32 \%$ reduction in food intake was seen acutely. This finding suggests that 
pharmacologically replicating the post-RYGB meal-stimulated increases in these hormones may be an effective therapeutic strategy for obesity.

66. Pathak, V., P.R. Flatt, and N. Irwin, Cholecystokinin (CCK) and related adjunct peptide therapies for the treatment of obesity and type 2 diabetes. Peptides, 2018. 100: p. 229-235.

67. Finan, B., et al., A rationally designed monomeric peptide triagonist corrects obesity and diabetes in rodents. Nature medicine, 2015. 21(1): p. 27.

68. Egerod, K.L., et al., A major lineage of enteroendocrine cells coexpress CCK, secretin, GIP, GLP1, PYY, and neurotensin but not somatostatin. Endocrinology, 2012. 153(12): p. 5782-5795.

69. Pocai, A., Action and therapeutic potential of oxyntomodulin. Molecular metabolism, 2014. 3(3): p. 241-251.

70. Dockray, G.J., Cholecystokinin. Current Opinion in Endocrinology, Diabetes and Obesity, 2012. 19(1): p. 8-12.

71. Brennan, I.M., et al., Effects of fat, protein, and carbohydrate and protein load on appetite, plasma cholecystokinin, peptide $Y Y$, and ghrelin, and energy intake in lean and obese men. American Journal of Physiology-Gastrointestinal and Liver Physiology, 2012. 303(1): p. G129G140.

72. Nauck, M.A. and J.J. Meier, Incretin hormones: Their role in health and disease. Diabetes Obes Metab, 2018. 20 Suppl 1: p. 5-21.

73. Grunddal, K.V., et al., Neurotensin Is Coexpressed, Coreleased, and Acts Together With GLP-1 and PYY in Enteroendocrine Control of Metabolism. Endocrinology, 2016. 157(1): p. 176-94.

74. Folgueira, C., et al., Uroguanylin levels in intestine and plasma are regulated by nutritional status in a leptin-dependent manner. Eur J Nutr, 2016. 55(2): p. 529-536.

*75. Di Guglielmo, M.D., et al., Immunohistochemical Staining for Uroguanylin, a Satiety Hormone, is Decreased in Intestinal Tissue Specimens From Female Adolescents With Obesity. Pediatr Dev Pathol, 2018. 21(3): p. 285-295.

Study investigating uroguanylin expression in children with obesity on biopsied samples of GI tissue and demonstrated reduced intestinal expression of uroguanylin levels in female but not male adolescents. This study highlights metabolic obesity-associated changes in the GI tract occur at young age.

76. Kentish, S.J., et al., Gastric vagal afferent modulation by leptin is influenced by food intake status. The Journal of Physiology, 2013. 591(Pt 7): p. 1921-1934.

77. Babaknejad, N., et al., An Overview of FGF19 and FGF21: The Therapeutic Role in the Treatment of the Metabolic Disorders and Obesity. Horm Metab Res, 2018. 50(6): p. 441-452.

78. Kuipers, F., V.W. Bloks, and A.K. Groen, Beyond intestinal soap [mdash] bile acids in metabolic control. Nature Reviews Endocrinology, 2014. 10(8): p. 488-498.

79. Bose, M., et al., Superior appetite hormone profile after equivalent weight loss by gastric bypass compared to gastric banding. Obesity, 2010. 18(6): p. 1085-1091.

80. Farey, J.E., et al., Effect of Laparoscopic Sleeve Gastrectomy on Fasting Gastrointestinal, Pancreatic, and Adipose-Derived Hormones and on Non-Esterified Fatty Acids. Obes Surg, 2017. 27(2): p. 399-407.

81. von Loeffelholz, C., et al., The anorexigenic peptide neurotensin relates to insulin sensitivity in obese patients after BPD or RYGB metabolic surgery. Int J Obes (Lond), 2018.

82. Grong, E., et al., Gastrin Secretion After Bariatric Surgery-Response to a Protein-Rich Mixed Meal Following Roux-En-Y Gastric Bypass and Sleeve Gastrectomy: a Pilot Study in Normoglycemic Women. Obes Surg, 2016. 26(7): p. 1448-56.

83. Bozadjieva, N., K.M. Heppner, and R.J. Seeley, Targeting FXR and FGF19 to Treat Metabolic Diseases-Lessons Learned From Bariatric Surgery. Diabetes, 2018. 67(9): p. 1720-1728. 
84. Gomez-Ambrosi, J., et al., FGF19 and FGF21 serum concentrations in human obesity and type 2 diabetes behave differently after diet- or surgically-induced weight loss. Clin Nutr, 2017. 36(3): p. 861-868.

85. Steinert, R.E., et al., Bile acids and gut peptide secretion after bariatric surgery: a 1-year prospective randomized pilot trial. Obesity (Silver Spring), 2013. 21(12): p. E660-8.

86. Biemann, R., et al., Serum bile acids and GLP-1 decrease following telemetric induced weight loss: results of a randomized controlled trial. Sci Rep, 2016. 6: p. 30173.

87. NovoNordisk. Novo Nordisk Pipeline. 201829 August 2018]; Available from: https://www.novonordisk.com/rnd/rd-pipeline.html.

88. Kojima, M., A. Hamamoto, and T. Sato, Ghrelin O-acyltransferase (GOAT), a specific enzyme that modifies ghrelin with a medium-chain fatty acid. J Biochem, 2016. 160(4): p. 189-194.

89. Norregaard, P.K., et al., A novel GIP analogue, ZP4165, enhances glucagon-like peptide-1induced body weight loss and improves glycaemic control in rodents. Diabetes Obes Metab, 2018. 20(1): p. 60-68.

90. sanofi. Sanofi Pipeline. 2018 [cited 201829 August 2018]; Available from: http://www.sanofi.co.uk///gb/en/layout.jsp?scat=84A599D7-CEEB-4EA0-B97B-

\section{F451E931E8B9.}

91. Lilly, E. Eli Lilly and Company Pipeline. [cited 201830 August 2018]; Available from: https://www.lilly.com/discovery/pipeline.

92. Wang, Y., J.D. Roth, and S.W. Taylor, Simultaneous quantification of the glucagon-like peptide1 (GLP-1) and cholecystokinin (CCK) receptor agonists in rodent plasma by on-line solid phase extraction and LC-MS/MS. J Chromatogr B Analyt Technol Biomed Life Sci, 2014. 957: p. 24-9. 